\title{
Impact of Weather on COVID-19 Pandemic in Various Locations of Jammu Division of Jammu Kashmir Union Territory, India
}

\author{
Mahender Singh ${ }^{1}$, Vishaw Vikas ${ }^{1 *}$, Rohit Sharma ${ }^{2}$ and Charu Sharma ${ }^{1}$ \\ ${ }^{1}$ Agrometeorology Section, Division of Agronomy, SKUAST Jammu, India \\ ${ }^{2}$ AMFU, RARS, Rajouri, SKUAST Jammu, India \\ *Corresponding author
}

\section{A B S T R A C T}

\section{Key w o r d s \\ Temperature, Humidity, COVID-19 cases \\ Article Info \\ Accepted: \\ 31 August 2020 \\ Available Online: \\ 10 September 2020}

\begin{abstract}
The aim of the study was to evaluate the impact of weather parameters i.e. temperature and humidity on COVID-19 spread in target locations of Jammu Division of Jammu Kashmir Union Territory, India. The timeline of data opted to analyze the weather parameters and COVID-19 cases were between $1^{\text {st }}$ July 2020 and $20^{\text {th }}$ August 2020. Pearson Correlation in SPSS 16.0 was implemented to define the magnitude of association between the number of daily new cases and weather parameters. During cumulative analysis of the entire region, it was found that the COVID-19 cases decreased with increase in temperature and vice-versa and there was significant increase in COVID-19 cases with increase in humidity levels of atmosphere and vice-versa. Therefore, the study results may guide authorities and policy makers on taking specific measures to the curb the weather based COVID-19 spread.
\end{abstract}

\section{Introduction}

After lockdown implemented amid COVID19 pandemic, the world has now entered a phase where we believe pandemics could be more common in future but this fiction movie like situation can be reversed if we stop the overexploitation of the nature and start utilizing its resources and other ecological components sustainably. Whenever such horrible situations are about to come, the mother earth has tried it's best to wave toward humans symbolizing control and management towards unfriendly behavior but selfishness has made us blind and sense less towards the simple gestures of nature. The 2002 SARS outbreak, 2009 swine flu pandemic, 2012 MERS pandemic (www.cdc.gov) and 2019 COVID pandemic are the clear answers of nature that we need to accept because of our failure to live in harmony and interpret these reflections to those who still have kept themselves isolated from practical biological world in the name of raising unsustainable economy.

Based on 2019 population projection by NCP report (RPP, 2019), the population of Jammu Kashmir is $1,32,03,000$. As on $26^{\text {th }}$ August 2020; 6:30 PM, the confirmed cases in Jammu Kashmir Union Territory were 34,411 out of which confirmed per million were 
2,558 per million i.e. 2,558 out of every 10 lakh people in Jammu and Kashmir have tested positive for the COVID-19 whereas the active ratio was $23 \%$ i.e. for every 100 confirmed cases nearly 22 were currently infected; moreover the recovery ratio was about $75.8 \%$ i.e. for every 100 confirmed cases approximately 76 have recovered from the virus but the fatality ratio was $1.9 \%$ i.e. for every 100 confirmed cases about 2 have unfortunately passed away from the virus; also the average growth rate was roughly $2 \%$, i.e. in the last one week; the number of new infections has grown by an average of $2 \%$ every day (www.covid19india.org). The outstanding efforts of the Jammu Kashmir administration has led to an increased testing efficiency with time and as a result of which COVID-19 test per million population has risen up to 67,267 (www.covid19india.org) which has curbed the pace of infection spread in the entire region.

COVID-19 or Coronavirus disease 2019 was first traced in Wuhan, China in December 2019 (Zhu et al., 2019). The World Health Organization declared COVID-19 as pandemic (WHO, 2020) because of its rapid spread in several countries outside China. In India, as on $26^{\text {th }}$ August 2020, 6.30 PM, there were 32,39,096 confirmed cases and 59,645 deaths (www.covid19india.org). COVID -19 first case in India was first reported in Kerala on January 30 and since then we have facing huge surge in cases number and was declared as Pandemic by WHO in mid-march 2020 (WHO, 2020). The control measures were opted to reduce the intensity of its spread with lockdown considered most effective option in lowering infection numbers; despite all protective measures and to reduce contamination, we still have noticed case rise of COVID-19 infection in subtropical region of Jammu Kashmir since the onset of monsoon causing rise in humidity levels across the region. According to $\mathrm{WHO}$, the symptoms of COVID-19 infection are fever, tiredness, dry cough, shortness of breath, aches, pains and sore throat. Recent studies have proved that COVID-19 spread through human-to-human transmission (Chan et al., 2020; Li et al., 2020; Wang et al., 2020). Certain climatic conditions can instigate the spread of disease (Tosepu et al., 2020). It has been proven already that temperature; humidity and wind speed are variables that can determine the survival and transmission of SARS virus and can be used in same case study too (Yuan et al., 2006). Virus can be transmitted through climatic factors also (Dalziel et al., 2018) but still the research on climate change vs. COVID-19 spread is limited, so this research and analysis can be a contribution in understanding the pattern and prevention of COVID-19 disease in future.

Thus, the present study is more aligned towards evaluating the correlation between meteorological parameters and COVID-19 pandemic.

\section{Materials and Methods}

The Jammu division study locations of Jammu Kashmir Union Territory were represented by Rajouri, Jammu and Kathua districts which fall in coordinates between $32.7266^{\circ} \mathrm{N}, 74.8570^{\circ} \mathrm{E}$ to $32.3863^{\circ} \mathrm{N}$, $75.5173^{\circ}$ E. The temperature $\left({ }^{\circ} \mathrm{C}\right)$ and humidity (\%) are considered as parameters of weather and the data related to weather parameters (from $I^{\text {st }}$ July 2020 to $20^{\text {th }}$ August 2020) was recorded from Agrometeorological Observatory situated at respective locations under study. The data related to COVID-19 cases in respective districts of same timeline was gathered from www.covid19india.org and same was analyzed graphically for the entire region (Fig. 1). Pearson Correlation in SPSS 16.0 was implemented to define the magnitude of association between the number of daily new cases and weather parameters. It 
summarizes the results and explains how well the association between daily transmission and weather parameters can bedemarcated.

\section{Results and Discussion}

The correlation results of weather parameters vs. COVID-19 cases in the study region have been highlighted in Table 1 and graphically in
Figure 2. During analysis, it was evaluated that the temperature was in significant negative correlation with COVID-19 cases in Jammu and Kathua; however it remained negatively non-significant in Rajouri and Reasi districts. During cumulative analysis of the entire locations, it was found that the COVID-19 cases decreased with increase in temperature and vice-versa.

Table.1 Correlation of coefficients among weather parameters vs. different districts and cumulative analysis of study locations of Jammu division of Jammu Kashmir Union Territory

\begin{tabular}{|c|c|c|}
\hline Jammu & Temperature & Humidity \\
\hline Humidity & $-0.749^{* *}$ & - \\
\hline COVID-19 Cases & $-0.298^{*}$ & $0.579 * *$ \\
\hline Rajouri & Temperature & Humidity \\
\hline Humidity & $-0.679^{* *}$ & - \\
\hline COVID-19 Cases & -0.122 & -0.107 \\
\hline Kathua & Temperature & Humidity \\
\hline Humidity & $-0.486^{* *}$ & - \\
\hline COVID-19 Cases & $-0.282^{*}$ & 0.075 \\
\hline Reasi & Temperature & Humidity \\
\hline Humidity & $-0.474 * *$ & - \\
\hline COVID-19 Cases & -0.273 & $0.407 * *$ \\
\hline Cumulative & Temperature & Humidity \\
\hline Humidity & $-0.507 * *$ & - \\
\hline COVID-19 Cases & $-0.504 * *$ & $0.611 * *$ \\
\hline
\end{tabular}

**Correlation is significant at $1 \%$ level of significance;

*Correlation is significant at $5 \%$ level of significance

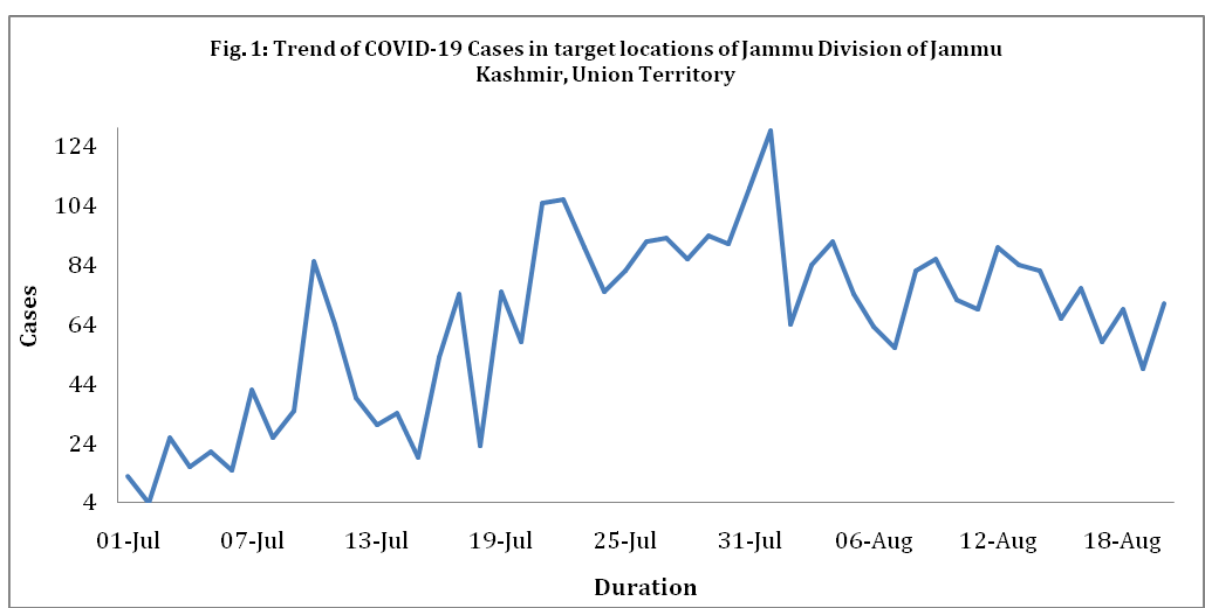




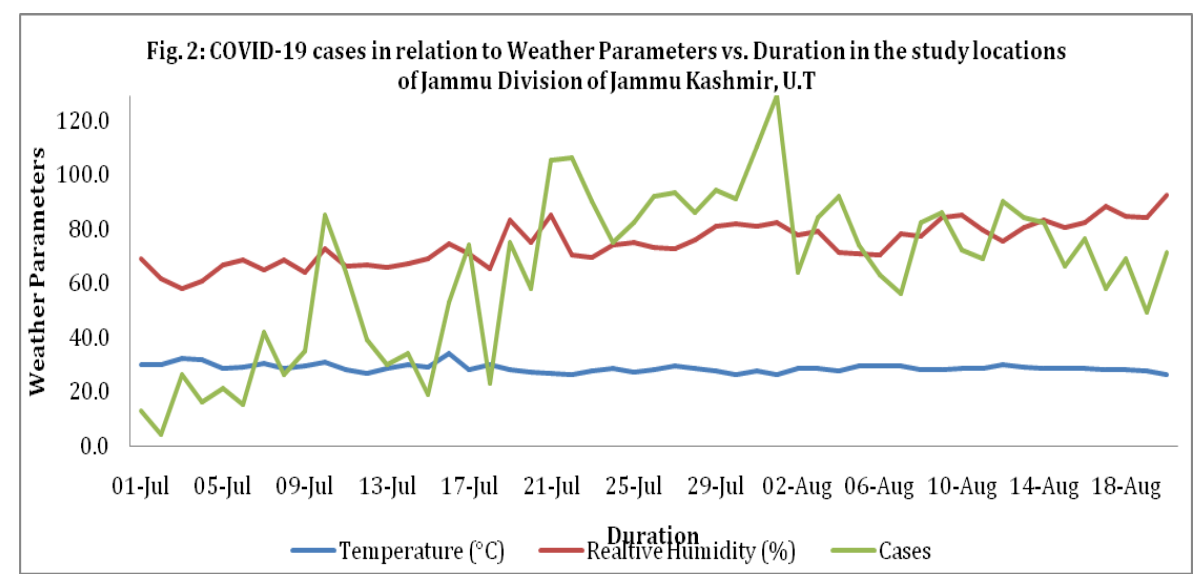

The humidity reflected a significant positive correlation with COVID-19 cases in Jammu and Reasi while Rajouri and Kathua observed non-significant positive correlation; however the cumulative analysis of entire study region highlighted the significant increase in COVID-19 cases with increase in humidity levels of atmosphere.

The same results were yielded in study carried out by Wang et al., 2020 in China which stated that Temperature and humidity have a strong influence with COVID cases. Another study by Sajadi et al., (2020) has also proven that temperature and humidity affects the distribution of seasonal behavior of respiratory viruses significantly which reflects the results of present study. The results with significant observations in this study are similar to the work of Chen et al., (2020) which demonstrated that the meteorological variables can predict worldwide outbreaks with high correlations with real data. In another study conducted at Wuhan which explained that there is a correlation between disease spread and weather, and such weather factors will suppress the disease when temperature rises (Guo et al., n.d.) which is in strong relation with the results of the current study. Worldwide it has also been noticed that the temperature and humidity has significantly affected the COVID-19 transmission (Chen et al., 2020) signifying the positive impact of our study. In another research by Ma et al., (2020); using similar parameters; it has been stated that temperature and humidity variations can influence the COVID-19 spread. A similar study was conducted by Tosepu et al., (2020) examined the correlation between weather andCOVID19 pandemic in Indonesia and found that the temperature average $\left({ }^{\circ} \mathrm{C}\right)$ is correlated with COVID-19 pandemic which was in association with our results. Also the results of Jammu, Kathua and entire region (cumulative) are in relation with the experiment conducted by Bi et al., (2007) in Beijing and Hongkong which was based on correlation of the weather parameters with SARS spread and the results reflected the negative correlation of temperature with SARS cases.

Despite in-depth analysis of weather and COVID-19 cases data, it should be acknowledged that this study has some limitations. Out of large number of weather parameters, very few are only considered for study and are confined to a particular region. Also, it should be mentioned that the role of weather in COVID-19 cases surge, can only be termed as correlation not causation at this point of time. Several other factors might also have acted as confounding factors in our correlational observations such as topography, testing facilities, related infrastructure, quarantine measures, population migration and policies like lockdown. In future, it is 
possible that more effective and efficient results can be yielded with the knowledge of combined effect of all confounding parameters stated above to fully understand the transmission dynamics.

In conclusion the study highlighted an important aspect of spread of COVID-19 cases in relation to weather parameters. This can play a major role in identifying the important areas which are vulnerable according to spread and those which are safe with slow growth rate in relation to weather parameters. In country like India where population density is very high, such study reflecting weather parameter as a factor to COVID-19 spread can help framing an efficient policy in disease control and management specially during onset of monsoon. Thus, our study can be used as a basis to understand the dynamics of COVID19 cases in relation to temperature and humidity in specific region.

\section{References}

Bi, P., Wang, J., Hiller, J.E., 2007. Weather: driving force behind the transmission of severed cold respiratory syndrome in China? Intern. Med. J. 37 (8), 550 554. https://doi.org/10.1111/j.14455994.2007.01358.x

Chan, J.F.-W., Yuan, S., Kok, K.-H., To, K.K.-W., Chu, H., Yang, J., Yuen, K.Y., 2020. A familial cluster of pneumonia associated with the 2019 novel coronavirus indicating personto-person transmission: a study of a family cluster. Lancet 395 (10223), 514-523. https://doi.org/10.1016/ S0140-6736(20)30154-9.

Chen B, Liang H, Yuan X, Hu Y, Xu M, Zhao $\mathrm{Y}$, et al. Roles of meteorological conditions inCOVID-19 transmission on a worldwide scale. Med. Rxiv 2020 .
Dalziel, B.D., Kissler, S., Gog, J.R., Viboud, C., Bjørnstad, O.N., Metcalf, C.J.E., et al., 2018.Ur-banization and humidity shape the intensity of influenza epidemics in U.S. cities. Science 362, $75-79$.

Guo X-J, Zhang H, Zeng Y-P. Transmissibility of COVID-19 and its Association with Temperature and Humidity.

Li, Q., Guan, X., Wu, P., Wang, X., Zhou, L., Tong, Y., Feng, Z., 2020. Early transmission dynamics in Wuhan, China, of novel coronavirus-infected pneumonia. N. Engl. J. Med.382 (13), 1199-1207.

https://doi.org/10.1056/NEJMoa20013 16.

Ma Y, Zhao Y, Liu J, He X, Wang B, Fu S, et al. Effects of temperature variation and humidity on the mortality of COVID19 in Wuhan. MedRxiv 2020.

Report on Population Projections for India and States, 2011-2036; National Commission on Population, MoHWF; 2019.

Sajadi, M.M., Habibzadeh, P., Vintzileos, A., Shokouhi, S., Miralles-Wilhelm, F., Amoroso, A., 2020. Temperature and latitude analysis to predict potential spread and seasonality for COVID-19. Available at SSRN 3550308.

Tosepu, R., Gunawan, J., Effendy, D.S., Ahmad, L.O.A.I., Lestari, H., Bahar, H., Asfian, P., 2020. Correlation between weather and Covid-19 pandemic in Jakarta, Indonesia. Sci. Total Environ., 138436https://doi.org/10.1016/j.scitote nv.2020.138436.

Wang, C., Horby, P.W., Hayden, F.G., Gao, G.F., 2020a. A novel coronavirus outbreak of global health concern. Lancet $395 \quad$ (10223), 470473.https://doi.org/10.1016/S01406736(20)30185-9. 
Wang, M., Jiang, A., Gong, L., Luo, L., Guo, W., Li, C., Li, H., 2020b. Temperature significant change COVID-19 transmission in 429 cities. medRxiv.https://doi.org/10.1101/2020. 02.22.200257912020.2002.2022.2002 5791.

World Health Organization (WHO), 2020. Coronavirus Disease 2019 (COVID19) Situation Report-78. Retrieved from. https://www.who.int/docs/ default-source/coronaviruse/situa-tionreports/20200407-sitrep-78-covid- 19.pdf?sfvrsn=bc43e1b_2. www.cdc.gov/museum/timeline/2000.html. CDC Timeline 2000s.

www.covid19india.org/state/JK; COVID-19 India. 2020.

Zhu, Y., Xie, J., 2020. Association between ambient temperature and COVID-19 infection in122 cities from China. Sci. Total Environ., 138-201. https://doi.org/10.1016/j.scitotenv.202 0.138201 .

\section{How to cite this article:}

Mahender Singh, Vishaw Vikas, Rohit Sharma and Charu Sharma. 2020. Impact of Weather on COVID-19 Pandemic in Various Locations of Jammu Division of Jammu Kashmir Union Territory, India. Int.J.Curr.Microbiol.App.Sci. 9(09): 1751-1756.

doi: https://doi.org/10.20546/ijcmas.2020.909.218 